Tohoku J. exp. Med., 1969, 98, 155-169

\title{
Clinical Evaluation of the Effect of Glyclopyramide in Diabetes Mellitus
}

\author{
Shoichi Yamagata, Yoshio Goto, Akira Ohneda, Jin Kikuchi, \\ Takayoshi Toyota, Norio Fukuhara, Shinichiro Sato and \\ Hideaki Sakai
}

\author{
The Medical Department (Prof. S. Yamagata), \\ Tohoku University School of Medicine, Sendai
}

A newly synthesized sulfonylurea, glyclopyramide (N-p-chlorobenzene sulfonyl, $\mathrm{N}^{\prime}$-pyrrolidinourea) was administered for a long period in 72 diabetic patients, including 25 inpatients and 47 outpatients.

The therapeutic effect of glyclopyramide was good in $30(79 \%)$ and fair in 4 of 38 patients of Group I, who had not been treated with any antidiabetic agents. Of 31 patients of Group II, who had not responded to another antidiabetics, 13 (48\%) responded excellently and $10(37 \%)$ fairly to the drug. Good control was achieved by glyclopyramide in 6 of the 7 diabetics of group III, who had been controlled by insulin less than 25 units daily. These results indicate that glyclopyramide gave good response in patients who had not been controlled by other oral antidiabetics, as well as in the patients treated initially with the drug, and that in some of insulin-requiring diabetes insulin could be replaced by glyclopyramide.

Glucose tolerance was improved after a long-term administration of glyclopyramide. Elevated serum total lipid or cholesterol was decreased by the treatment with glyclopyramide. Four patients showed minor side-effects in the gastrointestinal tract. It is proved that the administration of the drug for a long period did not produce any toxic effects on liver function and hemogram.

From this study it was concluded that glyclopyramide could be used successfully and safely in the treatment of diabetes mellitus.

Since 1955, when carbutamide was introduced as an antidiabetic agent, ${ }^{1}$ drugs of the sulfonylurea series have widely been used for their reliable therapeutic effects. However, because of the occasional side-effects the search continues for a drug whose predictable hypoglycemic action makes secondary failure unlikely, and which is devoid of significant toxicity. A new antidiabetic agent, glyelopyramide (Kyorin Pharmaceutical Co., Tokyo), is characterized chemically as N-p-chlorobenzen sulfonyl, $\mathrm{N}^{\prime}$-pyrolidinourea, and its structural formula is:

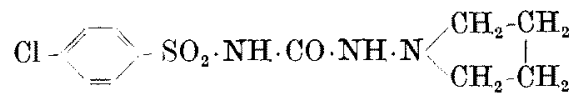

The present study is concerned with the clinical evaluation of the effect of this agent in diabetic patients.

\section{Materials and Methods}

\section{1) Patients}

The clinical studies were carried out in 72 diabetic patients at our clinic of the Tohoku University Hospital, consisting of 25 inpatients and 47 outpatients, of whom there were

Received for publication, February 22, 1969. 
TABLE 1. Clinical data of patients and

\begin{tabular}{|c|c|c|c|c|c|c|c|}
\hline \multirow[b]{2}{*}{ Patients } & \multirow{2}{*}{\multicolumn{2}{|c|}{$\begin{array}{l}\text { Age and } \\
\text { sex }\end{array}$}} & \multirow{2}{*}{$\begin{array}{l}\text { Duration } \\
\text { of disease } \\
\text { (years) }\end{array}$} & \multirow{2}{*}{$\begin{array}{l}\text { Body } \\
\text { weight } \\
\text { index }\end{array}$} & \multicolumn{3}{|c|}{ Glyclopyramide administration } \\
\hline & & & & & $\begin{array}{l}\text { Initial } \\
\text { doses } \\
(\mathrm{mg})\end{array}$ & $\begin{array}{c}\text { Mainte- } \\
\text { nance doses } \\
\text { (mg) }\end{array}$ & $\begin{array}{l}\text { Duration } \\
\text { (months) }\end{array}$ \\
\hline Group $I$ & & & & & & & \\
\hline M.H. & & $\mathbf{F}$ & 5 & 0.82 & 1250 & 1250 & 3 \\
\hline K.K. & & $\mathbf{M}$ & 15 & I. 12 & 1000 & 1000 & 18 \\
\hline K.A. & & $\mathbf{M}$ & $<1$ & 1.08 & 1250 & 250 & 7 \\
\hline M.C. & & $\mathrm{M}$ & $<1$ & 0.93 & 1500 & 1000 & 11 \\
\hline T.X. & & $\mathrm{F}$ & 1 & 0.83 & 1500 & 1250 & 1 \\
\hline S.K. & & $\mathbf{F}$ & $<1$ & 0.93 & 750 & 750 & 13 \\
\hline T.T. & 55 & $\mathbf{F}$ & $<1$ & 1.23 & 1500 & 250 & 10 \\
\hline F.A. & & $\mathbf{F}$ & 2 & 0.98 & 1000 & 750 & 14 \\
\hline H.N. & & $\mathrm{M}$ & 7 & 0.83 & 750 & 750 & 36 \\
\hline K.I. & 52 & $\mathbf{F}$ & $<1$ & 1.47 & 750 & 250 & 3 \\
\hline K.E. & 64 & $\mathbf{F}$ & $<1$ & 0.98 & 1000 & 250 & 14 \\
\hline I.It. & 56 & $\mathrm{M}$ & 5 & 0.98 & 500 & 750 & 2 \\
\hline S.U. & & F & 2 & 1.05 & 750 & 750 & 34 \\
\hline T.E. & 59 & $M$ & 6 & 1.14 & 750 & 250 & 2 \\
\hline K.S. & 62 & $\mathrm{~F}$ & $<1$ & 0.91 & 750 & 500 & 14 \\
\hline Ki.K. & 53 & $\mathrm{~F}$ & $<1$ & 1.15 & 750 & 500 & 4 \\
\hline I.K. & & $\mathrm{F}$ & 4 & 0.83 & 1500 & 500 & 3 \\
\hline To.Ta. & & M & $<1$ & 1.15 & 750 & 250 & 10 \\
\hline I.M. & 55 & $F$ & $<1$ & 0.92 & 750 & 250 & 36 \\
\hline C.K. & 33 & $\mathbf{M}$ & $<1$ & 0.98 & 750 & 500 & 4 \\
\hline Ta.Ta. & & $\mathbf{M}$ & $<1$ & 1.36 & 500 & 250 & 11 \\
\hline N.I. & & $\mathbf{M}$ & $<1$ & 1.05 & 750 & 500 & 1 \\
\hline K.O. & 57 & $\mathrm{~F}$ & $<1$ & 1.11 & 750 & 250 & 5 \\
\hline Y.T. & & $M$ & $<1$ & 0.91 & 750 & 500 & 21 \\
\hline Y.N. & & $\mathrm{F}$ & 18 & 1.14 & 500 & 750 & 12 \\
\hline S.E. & & $\mathrm{F}$ & $<1$ & 1.04 & 750 & 500 & 2 \\
\hline B.N. & 52 & M & 2 & 1.25 & 750 & 750 & 12 \\
\hline Sa.Ko. & 53 & $\mathrm{~F}$ & $<1$ & 0.92 & 500 & 250 & 2 \\
\hline To.Ta. & & $\mathrm{F}$ & 1 & 1.11 & 750 & 250 & 14 \\
\hline M.C. & 46 & $\mathbf{E}$ & 2 & 1.14 & 1000 & 500 & 6 \\
\hline S.O. & 65 & $M$ & 22 & 0.98 & 750 & 750 & 2 \\
\hline F.S. & 43 & $\mathbf{F}$ & 3 & 1.14 & 1000 & 500 & 5 \\
\hline A.Y. & 52 & M & $<1$ & 1.07 & 750 & 250 & 46 \\
\hline M.S. & 58 & $\mathrm{~F}$ & 1 & 1.16 & 1000 & 1000 & 9 \\
\hline M.H. & 49 & M & $<1$ & 1.22 & 500 & 375 & 13 \\
\hline T.O. & 57 & $\mathrm{M}$ & 20 & 1.40 & 500 & 500 & 1 \\
\hline M.A. & 66 & M & $<1$ & 1.29 & 750 & 750 & 1 \\
\hline S.O. & 56 & $\mathrm{~F}$ & $<1$ & 1.08 & 500 & 250 & 48 \\
\hline Group II & & & & & & & \\
\hline T.E. & 57 & $\mathrm{~F}$ & 1 & 0.90 & 1000 & 1000 & 22 \\
\hline H.S. & 63 & M & 20 & 0.97 & 750 & 750 & 12 \\
\hline Y.K. & 58 & $\mathrm{~F}$ & 1 & 0.96 & 750 & 500 & 58 \\
\hline S.N. & 66 & $\mathrm{~F}$ & 3 & 0.92 & 500 & 500 & 14 \\
\hline T.N. & 48 & $\mathrm{~F}$ & 1 & 0.96 & 1250 & 750 & 14 \\
\hline K.Is. & 55 & M & 1 & 1.20 & 1000 & 500 & 10 \\
\hline Su.Sa. & 49 & $\mathrm{~F}$ & 1 & 1.22 & 750 & 500 & 15 \\
\hline To.Ta. & 67 & $M$ & 8 & 1.00 & 500 & 250 & 5 \\
\hline Н.Т. & 54 & M & 1 & 1.02 & 750 & 500 & 48 \\
\hline Sh.s. & 46 & $M$ & 4 & 1.15 & 750 & 750 & 12 \\
\hline S.A. & 55 & M & 3 & 1.02 & 500 & 250 & 12 \\
\hline K.Ot. & 53 & M & 8 & 1.05 & 1000 & 1000 & 29 \\
\hline
\end{tabular}


response to glyclopyramide.

\begin{tabular}{|c|c|c|c|c|c|}
\hline \multicolumn{4}{|c|}{ Fasting blood sugar (mg \%) } & \multirow{3}{*}{$\begin{array}{c}\text { Treatment } \\
\text { before } \\
\text { glyclopyramide }\end{array}$} & \multirow{3}{*}{$\begin{array}{c}\text { Response } \\
\text { to } \\
\text { glyclopyramide }\end{array}$} \\
\hline \multirow{2}{*}{$\begin{array}{c}\text { Before } \\
\text { treatment }\end{array}$} & \multicolumn{3}{|c|}{ After treatment } & & \\
\hline & Maximum & Minimum & Mean & & \\
\hline 282 & 196 & 99 & 136 & None & Good \\
\hline 282 & 211 & 93 & 145 & None & Fair \\
\hline 250 & 131 & 68 & 93 & None & Good \\
\hline 235 & 146 & 103 & 133 & None & Good \\
\hline 231 & 138 & 94 & 116 & None & Good \\
\hline 228 & 173 & 113 & 139 & None & Fair \\
\hline 225 & 216 & 85 & 122 & None & Good \\
\hline 224 & 205 & 124 & 166 & None & Poor \\
\hline 208 & 161 & 99 & 151 & None & Fair \\
\hline 205 & 100 & 97 & 98 & None & Good \\
\hline 205 & 128 & 92 & 120 & None & Good \\
\hline 183 & 231 & 139 & 186 & None & Poor \\
\hline 182 & 178 & 89 & 130 & None & Good \\
\hline 179 & 109 & 76 & 89 & None & Good \\
\hline 177 & 155 & 101 & 129 & None & Good \\
\hline 174 & 165 & 69 & 114 & Nono & Good \\
\hline 173 & 132 & 95 & 123 & None & Good \\
\hline 169 & 120 & 78 & 96 & None & Good \\
\hline 165 & 130 & 87 & 118 & None & Good \\
\hline 163 & 142 & 110 & 124 & None & Good \\
\hline 161 & 160 & 92 & 118 & None & Good \\
\hline 160 & 112 & 99 & 105 & None & Good \\
\hline 158 & 133 & 87 & 97 & None & Good \\
\hline 153 & 153 & 88 & 117 & None & Good \\
\hline 151 & 210 & 130 & 169 & None & Poor \\
\hline 151 & 130 & 96 & 109 & None & Good \\
\hline 149 & 135 & 116 & 126 & None & Good \\
\hline 147 & 120 & 81 & 102 & None & Good \\
\hline 147 & 162 & 94 & 111 & None & Good \\
\hline 146 & 124 & 95 & 99 & None & Good \\
\hline 146 & 140 & 76 & 97 & None & Good \\
\hline 146 & 137 & 88 & 115 & None & Good \\
\hline 144 & 154 & 108 & 135 & None & Fair \\
\hline 143 & 195 & 121 & 149 & None & Poor \\
\hline 143 & 123 & 92 & 108 & None & Good \\
\hline 142 & 96 & 76 & 83 & None & Good \\
\hline 141 & 123 & 100 & 114 & None & Good \\
\hline 140 & 167 & 103 & 121 & None & Good \\
\hline 226 & 268 & 92 & 140 & Tolbutamide & Good \\
\hline 191 & 213 & 129 & 147 & Tolbutamide & Fair \\
\hline 181 & 137 & 100 & 125 & Tolbutamide & Good \\
\hline 172 & 212 & 85 & 141 & Tolbutamide & Fair \\
\hline 165 & 138 & 96 & 128 & Tolbutamide & Good \\
\hline 160 & 175 & 92 & 128 & Tolbutamide & Good \\
\hline 158 & 140 & 73 & 113 & Tolbutamide & Good \\
\hline 154 & 128 & 85 & 89 & Tolbutamide & Good \\
\hline 151 & 170 & 122 & 136 & Tolbutamide & Good \\
\hline 150 & 202 & 118 & 164 & Tolbutamide & Fair \\
\hline 149 & 140 & 72 & 96 & Tolbutamide & Good \\
\hline 144 & 182 & 118 & 141 & Tolbutamide & Fair \\
\hline
\end{tabular}


TABle 1. Continued.

\begin{tabular}{|c|c|c|c|c|c|c|c|}
\hline \multirow[b]{2}{*}{ Patients } & \multirow{2}{*}{\multicolumn{2}{|c|}{$\begin{array}{c}\text { Age and } \\
\text { sex }\end{array}$}} & \multirow[b]{2}{*}{$\begin{array}{l}\text { Duration } \\
\text { of disease } \\
\text { (years) }\end{array}$} & \multirow[b]{2}{*}{$\begin{array}{l}\text { Body } \\
\text { weight } \\
\text { index }\end{array}$} & \multicolumn{3}{|c|}{ Glyclopyramide administration } \\
\hline & & & & & $\begin{array}{l}\text { Initial } \\
\text { dosis } \\
\text { (mg) }\end{array}$ & $\begin{array}{l}\text { Mainten- } \\
\text { ance dosis } \\
\text { (mg) }\end{array}$ & $\begin{array}{l}\text { Duration } \\
\text { (months) }\end{array}$ \\
\hline S.H. & 49 & $\mathrm{~F}$ & 4 & 0.94 & 750 & 750 & 11 \\
\hline K.T. & & M & 5 & 0.91 & 1500 & 1500 & 1 \\
\hline M.W. & & $M$ & $<1$ & 0.98 & 750 & 500 & 34 \\
\hline A. 0 . & & $\mathrm{F}$ & 4 & 0.81 & 750 & 750 & 26 \\
\hline C.I. & & $\mathrm{F}$ & 1 & 1.04 & 500 & 500 & $\mathbf{2 5}$ \\
\hline H.Su. & & $\mathrm{F}$ & 1 & 0.96 & 750 & 250 & 25 \\
\hline Sh.O. & & M & 5 & 1.20 & 1000 & 750 & 11 \\
\hline T.D. & & $\mathrm{F}$ & 3 & 1.02 & 750 & 1000 & 16 \\
\hline T.K. & 53 & $\mathrm{~F}$ & 3 & 1.13 & 1000 & 1000 & 58 \\
\hline E.S. & & $\mathrm{F}$ & 5 & 1.34 & 750 & 750 & 36 \\
\hline Ko.K. & 60 & M & 30 & 0.95 & 750 & 750 & 31 \\
\hline K.S. & 69 & $\mathrm{~F}$ & 1 & 0.76 & 1000 & 500 & 33 \\
\hline Z.T. & 56 & $\mathrm{~F}$ & $<1$ & 0.89 & 1000 & 500 & 29 \\
\hline A.K. & 55 & $\mathrm{~F}$ & $<1$ & 0.85 & 1250 & 1250 & 14 \\
\hline Ke.S. & 57 & M & $<1$ & 0.91 & 1250 & 1500 & 1 \\
\hline \multicolumn{8}{|l|}{ Group III } \\
\hline Ka.T. & 21 & $\mathrm{~F}$ & 2 & 1.17 & 1500 & 500 & 15 \\
\hline Sh.Sa. & 34 & M & $<1$ & 1.29 & 750 & 750 & 12 \\
\hline Y.K. & 63 & M & 1 & 1.00 & 1000 & 250 & 17 \\
\hline Ka.Sa. & 14 & M & 1 & 0.81 & 1500 & 250 & 25 \\
\hline H.G. & & $\mathrm{F}$ & 4 & 1.00 & 750 & 750 & 39 \\
\hline To.Ch. & & $F$ & $<1$ & 0.94 & 1500 & 250 & 10 \\
\hline I.Ich. & 32 & M & $<1$ & 0.67 & 750 & 750 & 6 \\
\hline
\end{tabular}

39 females and 33 males. Inpatients were given dietary treatment under close observation for one or two weeks prior to starting medication. After fasting blood sugar was stabilized, the patients with a blood sugar level above $140 \mathrm{mg} \%$ with a urine sugar excretion above $10 \mathrm{~g}$ per day were selected for the study. Outpatients were initially prescribed a diabetic diet and observed for about two weeks. When the baseline blood sugar levels were still above $140 \mathrm{mg} \%$, the patients were chosen as test subjects.

The patients studied were presented in Table 1 and divided into three groups, Groups I, II and III. The patients of Group I including 38 diabetics were administered the sulfonylurea drug primarily Twenty-six patients of Group II were those who had been inadequately treated with other oral antidiabetic agents and showing fasting blood sugar above $140 \mathrm{mg} \%$. In seven patients of Group III, insulin was replaced by glyclopyramide without any change in dietary therapy only after they had achieved satisfactory control of the disease. Therefore, fasting blood sugar level of the Group III was below $140 \mathrm{mg} \%$.

\section{2) Method of clinical trial}

The initial doses of glyclopyramide were 1.0 to $1.5 \mathrm{~g}(4-6$ tablets) for patients whose fasting blood sugar exceeded $200 \mathrm{mg} \%$ and 0.5 to $0.75 \mathrm{~g}$ (2-3 tablets) for those below $200 \mathrm{mg} \%$. Daily dosage was decreased gradually as blood and urine sugar improved. The medication was given in divided doses one to three times daily before meals, and continued for one to 58 months, during which time the fasting blood sugar level of inpatients was determined once a week and their urinary sugar every day. The fasting blood sugar level of ontpatients was determined every two to four weeks. 


\begin{tabular}{|c|c|c|c|c|c|}
\hline \multicolumn{4}{|c|}{ Fasting blood suger (mg \%) } & \multirow[b]{2}{*}{$\begin{array}{c}\text { Treatment } \\
\text { before } \\
\text { glyclopyramide }\end{array}$} & \multirow[b]{2}{*}{$\begin{array}{c}\text { Response } \\
\text { to } \\
\text { glyolopyramide }\end{array}$} \\
\hline $\begin{array}{c}\text { Before } \\
\text { treamtent }\end{array}$ & Maximum & After treatment & Mean & & \\
\hline 201 & 248 & 160 & 217 & Chlorpropamide & Poor \\
\hline 181 & 265 & 201 & 243 & Tolinase & Poor \\
\hline 160 & 154 & 114 & 132 & Tolinase & Good \\
\hline 147 & 154 & 101 & 135 & Tolinase & Fair \\
\hline 148 & 174 & 109 & 120 & Chlorpentazide & Good \\
\hline 217 & 149 & 81 & 140 & Butylbiguanide & Fair \\
\hline 210 & 167 & 119 & 150 & Butylbiguanide & Fair \\
\hline 207 & 201 & 162 & 198 & Butylbiguanide & Poor \\
\hline 201 & 198 & 100 & 148 & Butylbiguanide & Fair \\
\hline 196 & 257 & 121 & 194 & Butylbiguanide & Poor \\
\hline 177 & 180 & 96 & 126 & $\begin{array}{l}\text { Dimethylbi- } \\
\text { guanide }\end{array}$ & Good \\
\hline 174 & 138 & 91 & 125 & Butylbiguanide & Good \\
\hline 170 & 183 & 112 & 141 & Butylbiguanide & Fair \\
\hline 215 & 249 & 117 & 146 & Glycodiazine & Fair \\
\hline 143 & 143 & 111 & 128 & Glycodiazine & Good \\
\hline 148 & 161 & & & & \\
\hline 132 & $\begin{array}{l}101 \\
137\end{array}$ & $\begin{array}{r}109 \\
90\end{array}$ & 130 & Insulin & Good \\
\hline 103 & 119 & $\begin{array}{l}90 \\
90\end{array}$ & 112 & Insulin & Good \\
\hline 120 & 126 & $\begin{array}{l}90 \\
69\end{array}$ & 110 & Insulin & Good \\
\hline 118 & 165 & $\begin{array}{l}69 \\
95\end{array}$ & 118 & Insulin & Good \\
\hline 121 & 159 & $\begin{array}{l}95 \\
86\end{array}$ & 119 & Insulin & Good \\
\hline 97 & 252 & $\begin{array}{r}86 \\
114\end{array}$ & 138 & Insulin & Good \\
\hline & & & 148 & Insulin & Poor \\
\hline
\end{tabular}

Samples of capillary blood were obtained from the ear lobe and analyzed for blood sugar by Fujita-Iwatake's method," which showed almost the same blood sugar as obtained by Hagedorn-Jensen's method. ${ }^{3}$ In our observation, normal fasting blood sugar level ranged between 80 and $120 \mathrm{mg} \%$.

The $50 \mathrm{~g}$ glucose tolerance test was carried out in 13 patients prior to and during the administration of the drug by the procedures described elsewhere. ${ }^{4}$

Fasting blood sample was obtained by venepuncture for the determination of serum lipid and liver function tests, and from the ear lobe for hemogram. Total lipid was determined by Bragdon's method ${ }^{5}$ and total cholesterol by Zak-Henly's method.6.7 The liver function tests were performed by following methods: thymol turbidity test (TTT) by Maclagan's method, ${ }^{8}$ zine turbidity test (ZTT) by Kunkel's method, ${ }^{9}$ glutamic pyruvic transaminase (GPT) and glutamic oxaloacetic transaminase (GOT) by the method of Reitman and Frankel ${ }^{10,11}$ and alkaline phosphatase by the method of Huggins and Talalay. ${ }^{12}$

\section{3) Criteria for evaluation of druy effect}

In this study the following criteria defined the therapeutic potency of glyclopyramide.

(1) Good-80\% of fasting blood sugar measurements below $140 \mathrm{mg} \%$.

(2) Fair-fasting blood sugar less than $160 \mathrm{mg} \%$ and reduced.

(3) Poor-fasting blood sugar remained above $160 \mathrm{mg} \%$.

Additionally, if fasting blood sugar is controlled below $140 \mathrm{mg} \%$ in patients treated with insulin (Group III) and can be remained at the same level by glyclopyramide, the effect was evaluated as good. 


\section{RESULTS}

\section{1) Effect of glyclopyramide on fasting blood sugar}

The effect of glyclopyramide on fasting blood sugar was summarized and its change in individual case was shown in Table 1. In Group I, 30 out of 38 patients $(79 \%)$ showed good response to the drug, while 4 patients of this group showed no response. In Group II, who did not show any good effect with other antidiabetics, 13 patients $(48 \%)$ responded excellently to the drug and $10(37 \%)$ showed fairly good response, while in 4 patients the drug did not show a good effect. This indicates that glyclopyramide is effective in the patients, who have not been treated with any drugs for diabetes mellitus. Also, the results suggest that patients of Group II mostly do not respond to the oral antidiabetic agents. Nevertheless, 10 out of 17 patients who had been treated by sulfonylurea drugs or biguanide other than glyclopyramide, showed good response to the latter. This suggests that glyclopyramide may be used in the patients who are resistant to other antidiabetics. In 6 patients of Group III, who had been treated with insulin, glyclopyramide could substitute for insulin. This result suggests the possibility that the the treatment of the patients requiring insulin less than 25 units daily may be controlled with glyclopyramide.

In total, $49(68 \%)$ out of 72 patients showed good response to the drug and 14 $(19.5 \%$ ) fairly good response, while $9(12.5 \%$ ) responded poorly (Table 2$)$.

In parallel to the change in fasting blood sugar glucosuria was reduced in all inpatients.

TABLE 2. The relation of drug effect to pretreatment of diabetes

\begin{tabular}{l|c|c|c|c}
\hline Group ( pretreatment) & Good & Fair & Poor & Total \\
\hline I (none) & 30 & 4 & 4 & 38 \\
II (oral antidiabetics) & 13 & 10 & 4 & 27 \\
III (insulin) & 6 & 0 & 1 & 7 \\
Total & $49(68.0)$ & $14(19.5)$ & $9(12.5)$ & $72(100)$
\end{tabular}

Numbers in parentheses represent percentages.

\section{2) Relation of baseline blood sugsr level to the effect of glyclopyramide}

As indicated in Table 3, glyclopyramide gave satisfactory results in 76 per cent of 54 patients with baseline blood sugar below $200 \mathrm{mg} \%$. The higher was the fasting blood sugar level, the less effective was the drug. The drug showed good effect in $8(44 \%)$ out of 18 patients with fasting blood sugar above $200 \mathrm{mg} \%$ and fairly good effect in 7 patients in this group. Most non-obese diabetic patients with fasting blood glucose $200 \mathrm{mg} \%$ usually require the treatment with insulin, but the results described above indicate that oral hypoglycemic agents may also be used successfully in cases with the fasting blood glucose level up to about $250 \mathrm{mg} \%$ (Table 3). 


\section{3) Influence of age on the effect of glyclopyramide}

The sulfonylurea drugs are generally more effective in diabetes occurring after age 40 , as in 62 patients of our series. However, Table 3 shows that glyclopyramide was also effective in 8 of 10 patients at the age of 40 years or less.

TABLE 3. Relation of drug effect to clinical pictures

\begin{tabular}{|c|c|c|c|c|}
\hline \multirow{2}{*}{ Group } & \multicolumn{3}{|c|}{ Drug effect } & \multirow{2}{*}{ Total } \\
\hline & Good & Fair & Poor & \\
\hline $\begin{array}{l}\text { Fasting blood sugar }(\mathrm{mg} \%) \\
\text { Below } 140 \\
141--160 \\
161--200 \\
\text { Above } 200\end{array}$ & $\begin{array}{r}5 \\
23 \\
13 \\
8\end{array}$ & $\begin{array}{l}0 \\
4 \\
3 \\
7\end{array}$ & $\begin{array}{l}1 \\
2 \\
3 \\
3 \\
\end{array}$ & $\begin{array}{r}6 \\
29 \\
19 \\
18\end{array}$ \\
\hline $\begin{array}{l}\text { Age (years) } \\
\text { Under } 40 \\
41--50 \\
51--60 \\
\text { Over } 61 \\
\end{array}$ & $\begin{array}{r}6 \\
10 \\
22 \\
11\end{array}$ & $\begin{array}{l}2 \\
2 \\
7 \\
3\end{array}$ & $\begin{array}{l}2 \\
3 \\
3 \\
1 \\
\end{array}$ & $\begin{array}{l}10 \\
15 \\
32 \\
15\end{array}$ \\
\hline $\begin{array}{c}\text { Body weight } \\
\text { Obese } \\
\text { Normal } \\
\text { Lean }\end{array}$ & $\begin{array}{r}9 \\
39 \\
1\end{array}$ & $\begin{array}{r}0 \\
14 \\
0\end{array}$ & $\begin{array}{l}1 \\
7 \\
1\end{array}$ & $\begin{array}{r}10 \\
60 \\
2\end{array}$ \\
\hline $\begin{array}{l}\text { Duration of disease (years) } \\
\text { Less than } 1 \\
1--5 \\
6-10 \\
\text { More than } 10\end{array}$ & $\begin{array}{r}24 \\
20 \\
2 \\
3\end{array}$ & $\begin{array}{l}4 \\
6 \\
2 \\
2\end{array}$ & $\begin{array}{l}1 \\
7 \\
0 \\
1\end{array}$ & $\begin{array}{r}29 \\
33 \\
4 \\
6\end{array}$ \\
\hline
\end{tabular}

\section{4) Influence of obesity on the effect of glyclopyramide}

Patients with body weight index above 1.21 were classified as obese, between 0.81 and 1.20 normal and less than 0.80 lean, based on the calculation from the desirable body weight of Japanese people..$^{13}$ As indicated in Table 3, the effectiveness of glyclopyramide treatment was unrelated to the body weight index. Body weight of patients who did not show a good response to the drug was mostly normal.

\section{5) Influence of duration of the disease on the effect of glyclopyramide}

Twenty-nine of 72 patients had been diagnosed within the preceding one year, and thirty-three, one to five years. The patients with short duration of the disease seem to respond better than the patients with long duration of the disease. Eighty-three per cent of 29 patients with the duration of the disease less than a year, excellently responded to the drug while 61 per cent of 33 patients with the duration of the disease of one to five years responded well. However, there is no statistically significant difference between above two groups $(\mathrm{p}<0.10)$. 
TABLE 4. Changes in glucose tolerance

\begin{tabular}{|c|c|c|c|c|c|c|}
\hline \multirow{3}{*}{ Patients } & \multicolumn{6}{|c|}{ Glucose tolerance before treatment $(\mathrm{mg} \%)$} \\
\hline & \multirow{2}{*}{ Before } & \multicolumn{4}{|c|}{$\begin{array}{l}\text { Minutes after } \\
\text { glucose load }\end{array}$} & \multirow{2}{*}{$\begin{array}{l}\text { Glucose } \\
\text { tolerance } \\
\text { index* }\end{array}$} \\
\hline & & 30 & 60 & 90 & 120 & \\
\hline K.I. & 223 & 320 & 334 & 354 & 244 & 295 \\
\hline K.E. & 185 & 280 & 357 & 390 & 370 & 316 \\
\hline T.E. & 161 & 204 & 316 & 280 & 258 & 241 \\
\hline N.I. & 172 & 236 & 292 & 264 & 228 & 238 \\
\hline K.O. & 177 & 222 & 236 & 354 & 292 & 256 \\
\hline S.E. & 151 & 261 & 313 & 290 & 266 & 256 \\
\hline M.C. & 176 & 272 & 292 & 317 & 306 & 273 \\
\hline S.O. & 182 & 239 & 320 & 356 & 320 & 283 \\
\hline A. Y. & 229 & 358 & 388 & 348 & 316 & 328 \\
\hline T.O. & 142 & 186 & 201 & 203 & 177 & 182 \\
\hline Z.T. & 212 & 312 & 348 & 340 & 368 & 316 \\
\hline K.S. & 205 & 258 & 356 & 367 & 382 & 319 \\
\hline S.S. & 226 & 368 & 420 & 388 & 362 & 353 \\
\hline Mean & 188 & 273 & 321 & 327 & 299 & 281 \\
\hline $\begin{array}{c} \pm \\
\text { SEM }\end{array}$ & 7.9 & 15.6 & 30.3 & 14.7 & 17.3 & 12.8 \\
\hline
\end{tabular}

Moreover, good therapeutic effects were observed in three out of six patients with the disease for more than ten years. This suggests that glyclopyramide may be used effectively even in long-standing diabetes (Table 3).

\section{6) Glucose tolerance before and after glyclopyramide}

Oral glucose tolerance test in 13 patients verified the therapeutic effectiveness of glyclopyramide, since the blood sugar curve improved in every patient (Table 4). Mean blood sugar values before the treatment were 188 ( $\pm \mathrm{SE} 7.9) \mathrm{mg} \%$ at the fasting, $327 \pm 14.7 \mathrm{mg} \%$ at the peak and $299 \pm 17.3 \mathrm{mg} \% 2$ hours after glucose load, whereas during the drug administration they were $111 \pm 6.4 \mathrm{mg} \%$ at the fasting, $236 \pm 12.4 \mathrm{mg} \%$ at the peak and $219 \pm 12.6 \mathrm{mg} \% 2$ hours after glucose load. In three patients with frank diabetic curve before the treatment the blood sugar curve reverted to 'borderline' after long-term administration of glyclopyramide. (The criteria for a diabetic curve is $200 \mathrm{mg} \%$ or higher at the peak and 2 hour level of $140 \mathrm{mg} \%$ or more ${ }^{4}$ ). The mean glucose tolerance index, the mean value of five blood sugar levels during glucose tolerance test, was $281 \pm 12.8 \mathrm{mg} \%$ before glyclopyramide administration and $196 \pm 9.0 \mathrm{mg} \%$ after the drug therapy. The difference between glucose tolerance indexes before and after the treatment was statistically significant $(\mathrm{p}<0.001)$.

\section{7) Effect of glyclopyramide on serum lipid and cholesterol}

Serum total lipids were measured in 28 patients before and after the administration of glyclopyramide. Elevated level of serum lipid above $700 \mathrm{mg} \%$ was observed in 14 out of 28 patients before glyclopyramide administration, the 
after glyclopyramide administration

\begin{tabular}{r|r|r|r|r}
\hline \multicolumn{5}{|c|}{ Glucose tolerance after treatment } \\
\hline
\end{tabular}

levels during glucose tolerance test.

TABLE 5. Effect of glyclopyramide on serum total lipid and cholesterol A. Total lipid (mg \%)

\begin{tabular}{|c|c|c|}
\hline Patients & Before treatment & After treatment \\
\hline K.A. & 1231 & 536 \\
\hline Y.T. & 769 & 483 \\
\hline Y.N. & 728 & 570 \\
\hline S.E. & 1046 & 929 \\
\hline S.K. & 737 & 731 \\
\hline T.O. & 761 & 582 \\
\hline T.E. & 1086 & 594 \\
\hline H.S. & 710 & 757 \\
\hline S.S. & 868 & 853 \\
\hline T.T. & 737 & 621 \\
\hline Sh.S. & 1027 & 653 \\
\hline A. 0 . & 959 & 801 \\
\hline T.K. & 844 & 676 \\
\hline Z.T. & 768 & 644 \\
\hline Mean \pm SEM & $876.5 \pm 44.1$ & $673.6 \pm * 33.8$ \\
\hline H.N. & 501 & 658 \\
\hline K.I. & 647 & 685 \\
\hline I.M. & 483 & 536 \\
\hline Ta.T. & 620 & 716 \\
\hline N.I. & 690 & 579 \\
\hline K.Og. & 608 & 825 \\
\hline F.S. & 494 & 505 \\
\hline Y.K. & 505 & 507 \\
\hline S.N. & 422 & 664 \\
\hline Ki.Is. & 650 & 524 \\
\hline H.T. & 503 & 408 \\
\hline S.A. & 652 & 538 \\
\hline $\mathrm{Ka} . \mathrm{O}$ & 641 & 522 \\
\hline C.I. & 583 & 819 \\
\hline Mean $\pm \mathrm{SEM}$ & $571.4 \pm 22.4$ & $609.1 \pm 33.3_{+}^{+}$ \\
\hline
\end{tabular}


Table 5. Continued.

B. Cholesterol $(m g \%)$

\begin{tabular}{|c|c|c|c|c|c|}
\hline Patients & $\begin{array}{c}\text { Before } \\
\text { treatment }\end{array}$ & $\begin{array}{c}\text { After } \\
\text { treatment }\end{array}$ & Patients & $\begin{array}{c}\text { Before } \\
\text { treatment }\end{array}$ & $\begin{array}{l}\text { Afeter } \\
\text { treament }\end{array}$ \\
\hline $\begin{array}{l}\text { K.K. } \\
\text { K.A. } \\
\text { K.I. } \\
\text { Y.T. } \\
\text { S.E. } \\
\text { S.K. } \\
\text { T.O. } \\
\text { S.O. } \\
\text { T.E. } \\
\text { T.N. } \\
\text { T.T. } \\
\text { S.S. } \\
\text { A.O. } \\
\text { T.K. } \\
\text { A.T. } \\
\text { Mean } \\
\pm \text { SEM }\end{array}$ & $\begin{array}{c}280 \\
314 \\
272 \\
298 \\
350 \\
268 \\
276 \\
269 \\
276 \\
350 \\
262 \\
260 \\
308 \\
250 \\
491 \\
301.6 \\
15.7\end{array}$ & $\begin{array}{l}194 \\
274 \\
232 \\
230 \\
322 \\
208 \\
351 \\
232 \\
216 \\
198 \\
246 \\
284 \\
256 \\
234 \\
478 \\
263.7 \dagger \\
19.1\end{array}$ & $\begin{array}{l}\text { H.N. } \\
\text { S.U. } \\
\text { I.M. } \\
\text { Ta.T. } \\
\text { N.I. } \\
\text { K.Og. } \\
\text { Y.N. } \\
\text { F.S. } \\
\text { A.Y. } \\
\text { H.S. } \\
\text { Y.K. } \\
\text { S.N. } \\
\text { K.Is. } \\
\text { Su.S. } \\
\text { H.T. } \\
\text { S.A. } \\
\text { K.O. } \\
\text { C.I. } \\
\text { Ha.S. } \\
\text { Ko.K. } \\
\text { K.S. } \\
\text { Z.T. } \\
\text { Y.K. } \\
\text { H.G. } \\
\text { Mean } \\
\text { 土SEM }\end{array}$ & $\begin{array}{c}204 \\
206 \\
155 \\
203 \\
240 \\
210 \\
147 \\
194 \\
160 \\
218 \\
141 \\
150 \\
204 \\
230 \\
183 \\
214 \\
232 \\
166 \\
218 \\
192 \\
170 \\
243 \\
202 \\
215 \\
195.7 \\
6.2\end{array}$ & $\begin{array}{r}224 \\
210 \\
176 \\
220 \\
228 \\
202 \\
170 \\
172 \\
194 \\
218 \\
162 \\
194 \\
180 \\
204 \\
136 \\
248 \\
246 \\
268 \\
270 \\
186 \\
186 \\
186 \\
210 \\
282 \\
207.2 \\
74 \ddagger\end{array}$ \\
\hline
\end{tabular}

remaining 14 patients showing normal level of lipid. Following the drug therapy, elevated lipids fell in 13 of 14 patients. Total serum lipids of the patients with initial value below $700 \mathrm{mg} \%$ became normal after the treatment with glyclopyramide in all patients except three, whose total lipids rose above $700 \mathrm{mg} \%$ after the drug therapy. The mean level of total lipids in the patients whose initial level of lipid exceeded $700 \mathrm{mg} \%$ was $876.5 \pm 44.1 \mathrm{mg} \%$ before the drug administration and fell to $673.6 \pm 33.8 \mathrm{mg} \%$ after the medication. This decrease in total serum lipids was statistically significant $(\mathrm{p}<0.001)$ (Table 5-A).

Total serum cholesterol was measured before and after glyclopyramide in 39 diabetics, of whom 15 patients showed the total cholesterol level above $250 \mathrm{mg} \%$ and 24 patients below $250 \mathrm{mg} \%$ before the drug therapy. Serum cholesterol fell after the drug therapy in 13 of 15 patients with high level of initial cholesterol. Cholesterol level changed normal in all patients with cholesterol below $250 \mathrm{mg} \%$ except for two patients whose cholesterol elevated after the drug therapy. The mean cholesterol level of the patients with initial high value was $301.6 \pm 15.7 \mathrm{mg} \%$ before therapy and fell to $26.37 \pm 19.1 \mathrm{mg} \%$ after the drug therapy (Table $5-\mathrm{B}$ ). The decrease in total serum cholesterol was statistically significant $(\mathrm{p}<0.01)$. 
These results suggest the possibility of improvement in serum total lipids and cholesterol by the glyclopyramide treatment.

\section{8) Toxicity of glyclopyramide on liver and hemogram}

Liver function tests were done in 20 patients before and during the administration of glyclopyramide. Complete blood counts were carried out in 12 patients before and during the drug administration. No abnormality developed in either the liver profile (Table 6) or the hemogram (Table 7).

TABLE 6. Effect of glyclopyramide on liver function test*

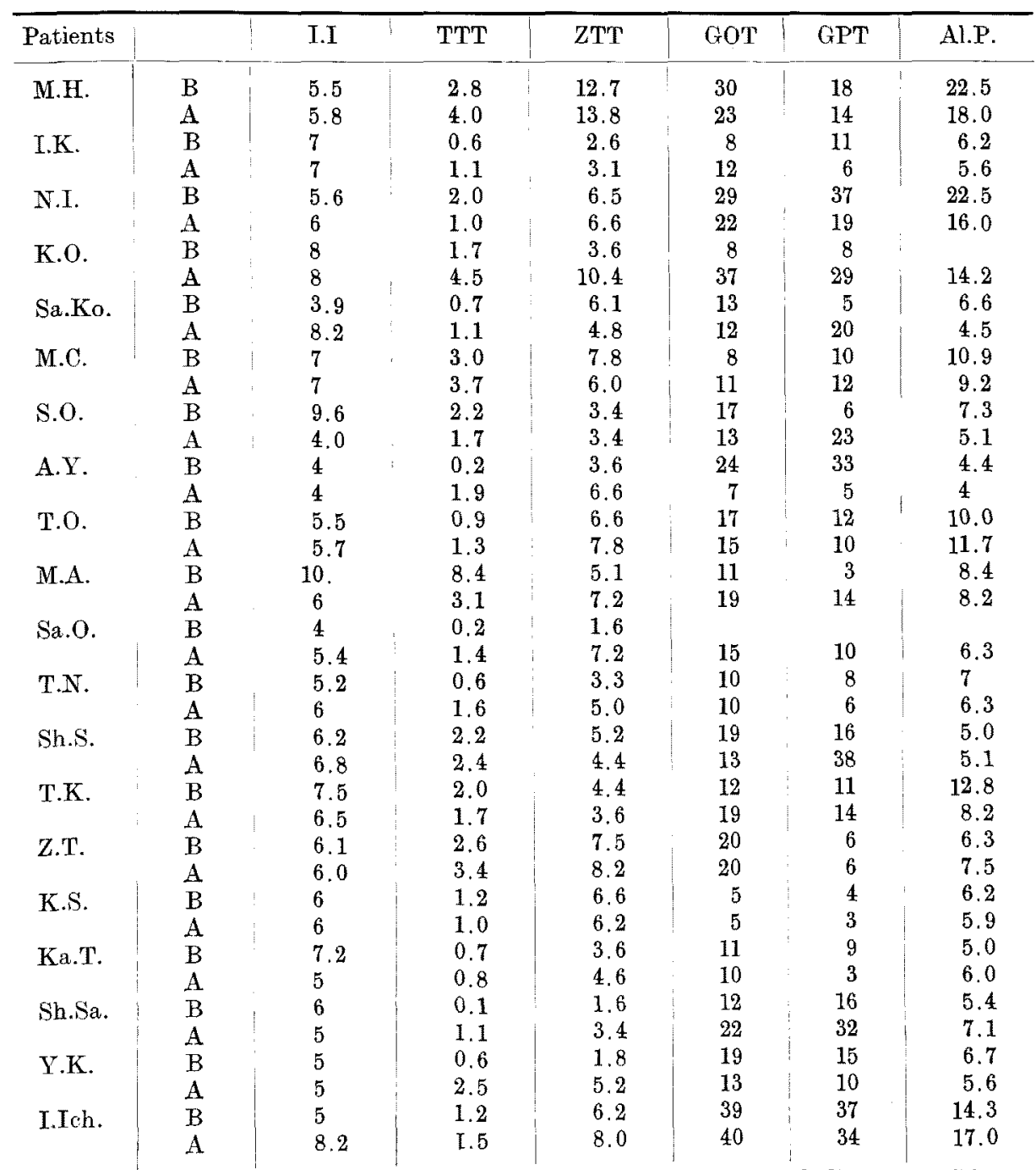

* I.I., icterus index; TTT, thymol turbidity test; ZTT, zinc turbidity test; GOT, glutamic oxaloacetic transaminase; GPT, glutamic pyruvic transaminase; and Al.P., alkaline phosphatase. Numbers express the unit in each measurement. B and A, mean before and after the treatment with glyclopyramide, respectively. 
TABLE 7. Effect of glyclopyramide on hemogram

\begin{tabular}{|c|c|c|c|c|}
\hline Patients & \multicolumn{2}{|c|}{ White blood cell } & $\begin{array}{l}\text { Red blood cell } \\
\text { (million) }\end{array}$ & $\begin{array}{c}\text { Heroglobin } \\
(\%)\end{array}$ \\
\hline M.S. & $\begin{array}{l}\mathrm{B} * \\
\mathrm{~A}\end{array}$ & $\begin{array}{l}8225 \\
9,250\end{array}$ & $\begin{array}{l}4.54 \\
4.26\end{array}$ & $\begin{array}{l}70 \\
89\end{array}$ \\
\hline \multirow[t]{2}{*}{ T.E. } & B & 10,000 & 3.71 & 94 \\
\hline & A & 10,700 & 3,94 & 82 \\
\hline \multirow[t]{2}{*}{ N.I. } & $\mathrm{B}$ & 5,000 & 4.83 & 98 \\
\hline & A & 4,500 & 4.54 & 96 \\
\hline \multirow[t]{2}{*}{ S.K. } & $\mathrm{B}$ & 6,200 & 4.28 & 85 \\
\hline & $\mathrm{A}$ & 6,500 & 4.56 & 90 \\
\hline \multirow{2}{*}{ M.C. } & $\bar{B}$ & 5,200 & 3.93 & 83 \\
\hline & A & 5,045 & 4.91 & 94 \\
\hline \multirow[t]{2}{*}{ S.O. } & $\bar{B}$ & 4,700 & 4.32 & 110 \\
\hline & A & 7,600 & 4.84 & 94 \\
\hline \multirow{2}{*}{ T.N. } & $\mathrm{B}$ & 6,600 & 4.28 & 80 \\
\hline & $A$ & 5,900 & 4.17 & 78 \\
\hline \multirow[t]{2}{*}{ Sh.S. } & $\mathrm{B}$ & 7,000 & 5.10 & 116 \\
\hline & A & 6,375 & 4.25 & 92 \\
\hline \multirow[t]{2}{*}{ Z.T. } & $\mathrm{B}$ & 5,800 & 4.91 & 88 \\
\hline & A & 6,400 & 5.02 & 90 \\
\hline \multirow{2}{*}{ K.S. } & $\mathrm{B}$ & 5,250 & 4.23 & 80 \\
\hline & A & 7,200 & 4.10 & 86 \\
\hline \multirow{2}{*}{ Sh.Sa. } & $\mathrm{B}$ & 8,050 & 4.65 & 102 \\
\hline & A & 8,150 & 5.05 & 110 \\
\hline \multirow{2}{*}{ Y.K. } & $\mathrm{B}$ & 6,750 & 4.10 & 100 \\
\hline & $\mathrm{A}$ & 7,200 & 4.20 & 90 \\
\hline
\end{tabular}

\section{9) Side-effects of glyclopyramide}

Four of 72 patients developed minor side effects. Three individuals developed gastrointestinal symptoms, including constipation, mild abdominal pain and distention. The other patients experienced general malaise. The drug was not discontinued in these cases. All side-effects manifested themselves within a week after starting the administration of glyclopyramide.

\section{Discussion}

A newly synthesized sulfonylurea, glyclopyramide, showed good effect in 68 per cent of 72 diabetic patients, and fair effect in 20 per cent of them. A survey of the reports on glyclopyramide published in Japan ${ }^{14-20}$ shows that good response to the drug was obsurved in 175 out of 206 diabetic patients, although the criteria for the evaluation of the drug effect varies more or less in different reports. These results, including our own, indicate that the drug produced the same effect as other sulfonylurea drugs widely used.

From the analysis of the relationship of the drug effect to clinical pictures, patients with mild diabetes or short duration of the disease usually showed good response. However, it should be noted that glyclopyramide exerted good effect on the patients whose fasting blood sugar was higher than $200 \mathrm{mg} \%$ or in those who were 
failed to respond well to other antidiabetic agents. Furthermore, insulin was successfully replaced by glyclopyramide in 6 out of 7 diabetic patients who were treated with 25 units or less of insulin per day.

Blood sugar lowering effect of glyclopyramide might be due to increased secretion of insulin from the pancreas. In other experiments with a group of four anesthetized dogs, ${ }^{21}$ venous blood sugar fell to the mean nadir of $72 \mathrm{mg} \%$ from the baseline level of $105 \mathrm{mg} \%$ following the injection of glyclopyramide in a dose of $50 \mathrm{mg}$ per $\mathrm{kg}$ of body weight. Plasma insulin concentration of the upper pancreaticoduodenal vein abruptly rose within 15 minutes after the drug administration. The result in one dog is shown in Fig. 1. Plasma insulin concentration in the upper pancreaticoduodenal vein rose much higher after the injection of glyclopyramide in a dose of $50 \mathrm{mg}$ per $\mathrm{kg}$ of body weight in comparison with the results obtained in a dog injected the same amount of tolbutamide. These results are compatible with the observation of Oda et al..$^{14}$ that the potency ratio of glyclopyramide against tolbutamide was 2.66 based on the hypoglycemic effect in rats.
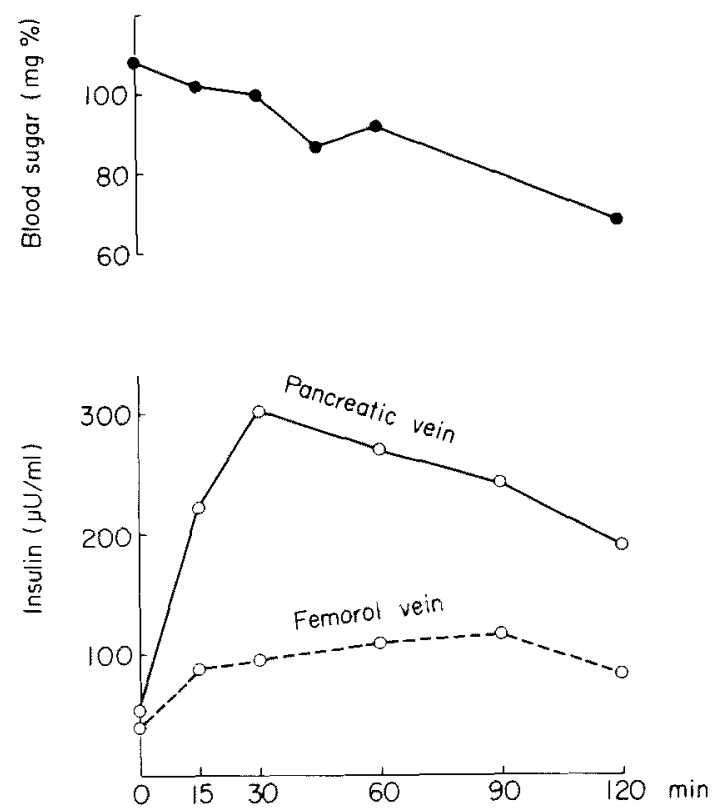

Fig. 1. Effects of the intravenous administration of glyclopyramide in a dose of $50 \mathrm{mg}$ per $\mathrm{kg}$ body weight upon blood sugar and plasma insulin in the pancreatic vein and the femoral vein of an anesthetized dog.

The drug, when administered by mouth at fasting, is absorbed very slowly as described elsewhere. ${ }^{21}$ Plasma concentration of glyclopyramide in healthy volunteers rose gradually and reached the peak 60 minutes after the administration of one gram of glyclopyramide, the high level being maintained during three hours. When one gram of glyclopyramide was given at fasting with $2 \mathrm{~g}$ of sodium bicarbonate, 
glyclopyramide was absorbed rapidly and its concentration in plasma reached the peak during first 30 minutes. It is supposed that the plasma concentration of glyclopyramide can be maintained in the long-term administration of the drug by following possible reasons; (1) diet ingestion enhances the absorption of the drug thorugh the rise in $\mathrm{pH}$ and the increased solubility (2) glyclopyramide can be absorbed easily through the change in the intestine by long-term administration of the drug, and (3) accumulation of the drug in blood by slow absorption. Glyclopyramide is broken down in the body to chlorobenzene sulfonamide, pyrrolidine and urea which are excreted into urine (T. T. Irikura, unpublished). It is indicated from the results of experiments with rabbits and human subjects that half life time of glyclopyramide is about three hours in the body. ${ }^{14,21}$

As described above, there are few minor side-effects but no toxicity on the liver function or hemogram was observed. In the reports by various authors in Japan, there were described only few side-effects such as disturbance in the gastrointestinal tract. ${ }^{14-20}$ From these facts it may be concluded that glyclopyramide is a therapeutically effective oral antidiabetic agent which can be used with safety.

\section{Acknowledgment}

We shonld like to thank Dr. Holbrooke S. Seltzer for his helpful criticism.

\section{References}

1) Franke, H. \& Fuchs, J. Ein neues antidiabetisches Prinzip. Ergebnisse klinischer Untersuchungen. Dtsch. med. Wischr., 1955, 80, 1449-1452.

2) Fujita, A. \& Iwatake, D. Bestimmung des echten Blutzuckers ohne Hefe. Biochem. Zschr., 1931, 242, 43-60.

3) Hagedorn, H.C. \& Jensen, B.N. Zur Mikrobestimmung des Blutzuckers mittels Ferricyanid. Biochem. Z., 1923, 135, 46-58.

4) Goto, Y., Takanami, A., Kato, J. \& Ohneda, A. Detection of prediabetes by glucosetolerance test sensitised by prednisolone. Lancet, 1960, 2, 461-465.

5) Bragdon, J.H. Method for determination of total serum lipid. In: Lipid and the Steroid Hormones in Clinical Medicine, edited by F.W. Sunderman, Lippincott, Philadelphia and Montreal, 1960, pp. 9-14.

6) Zak, B. Simple rapid microtechnic for serum total cholesterol. Amer. J. clin. Path., $1957,27,583-588$.

7) Henly, A.H. The detemination of serum cholesterol. Analyst, 1957, 82, 286-287.

8) Maclagan, N.F. The thymol turbidity test as an indicator of liver dysfunction. Brit. $J$. exp. Path., 1944, 25, 234-241.

9) Kunkel, H.G. Estimation of alteration of serum globulin by a turbidimetric technique. Proc. Soc. exp. Biol. Med., 1947, 66, 217-224.

10) Peitman, S. \& Frankel, S. A colorimetric method for the determination of serum glutamic oxalacetic and glutamic pyruvic transaminases. Amer. J. clin. Path., 1957, 28, $56-63$.

11) Sigma Pharmaceutical Co. Technical Bulletin, 1961, No. 505.

12) Huggins, C. \& Talalay, P. Sodium phenolphthalein phosphate as a substrate for phosphatase tests. J. biol. Chem., 1945, 159, 399-4l0.

13) Goto, Y. \& Wakui, A. Ideal body weight and target body weight in diabetic patient. Naika (Jap.), 1961, 8, 1153-1159.

14) Oda, T., Oka, H. \& Kaneko, T. Studies on oral antidiabetic, 1-p-chlorobenzensulfonyln-pyrrolidinourea. Chiryo (Jap.), 1965, 47, 843-846. 
15) Onishi, Y., Kusumoto, T., Takano, T., Takayama, A., Miyashita, T. \& Yamabuki, T. Clinical experience of new oral diabetic agent, Deamelin S. Shinyaku to Rinsho (Jap.), 1965, 14, 1323-1328.

16) Akazawa. Y. Clinical experience of Deamelin S. Shinryo to Shinyaku (Jap.), 1966, 3, 1211-1212.

17) Shigeta, Y., Hoshi, M., Ko, B. \& Inoue, M. Treatment of diabetic patients with Deamelin S. Shinryo (Jap.), 1966, 19, 1391-1394.

18) Nakano, K., Yamashiro, C., Matsuura, M., Nishioka, M. \& Miki, S. Clinical studies on new oral antidiabetic agent, Deamelin S. Shinryo to Shinyaku (Jap.), 1967, 4, 434-436.

19) Mimura. G., Jinnai, T., Nakamura, T., Ono, K., Nagasaki, U. \& Akiyoshi, S. Longterm administration of new oral antidiabetic agent, $N$-p-chlorobenzene sulfonyl $N$ pyrrolidinourea. Shinryo to Shinyaku (Jap.), J.968, 5, 1045-1048.

20) Yoshikawa, K. Treatment of diabetes mellitus with Deamelin S. Shinryo to Shinyaku (Jap.), 1968, 5, 647-654.

21) Yamagata, S., Goto, Y., Ohneda, A., Anzai, M., Kawashima, S., Kikuchi, J., Yamauchi, Y., Toyota, T., Mizuhara, F. \& Fukuhara, N. Mechanism and response test of Deamelin $S$ in respect of changes in blood insulin. Shinryo to Shinyaku (Jap.), 1967, 4, 429-433. 